\title{
Concentrations of Soil Potassium after Long-Term Organic Dairy Production
}

\author{
Anne-Kristin Løes ${ }^{1}$ and Anne Falk Øgaard ${ }^{2}$ \\ ${ }^{1}$ Norwegian Centre for Ecological Agriculture (NORSØK), N-6630 Tingvoll, Norway; ${ }^{2}$ Department of Soil and Water \\ Sciences, Agricultural University of Norway, Box 5028, N-1432 Ås, Norway
}

\begin{abstract}
On five long-term organic dairy farms aiming at selfsufficiency with nutrients, soil concentrations of ammonium-acetate lactate extractable potassium (K$\mathrm{AL}$ ) and acid-soluble $\mathrm{K}$ was measured twice in topsoil $(0-20 \mathrm{~cm})$ and subsoil $(20-40 \mathrm{~cm})$ over periods of $6-$ 14 years. Organic management had occurred for $>9$ years at the second sampling. On average there were most probably field level K-deficits. Even so, topsoil K-AL concentrations were medium high (65-155 mg $\mathrm{K} \mathrm{kg}^{-1}$ soil), and did not decrease during the study period. However, for three farms, topsoil K-AL was approaching a minimum level determined by soil texture, where further decrease is slow. Subsoil K-AL concentrations were generally low $(<65)$. The soils were mostly light-textured, and reserves of K-releasing soil minerals (illite) were low, never exceeding $6 \%$ of the mineral particles $<2 \mathrm{~mm}$ diameter. Topsoil acidsoluble $\mathrm{K}$ concentrations were low $\left(<300 \mathrm{mg} \mathrm{K} \mathrm{kg} \mathrm{k}^{-1}\right.$ soil) on two farms, medium (300-800) on three farms and decreased significantly on one farm. Cationexchange capacity increased on two farms. This may indicate increased amount of expanded clay minerals caused by K-depletion. On self-sufficient organic dairy farms, purchased nutrients will be required by low soil nutrient reserves to avoid seriously decreased yields and quality of crops.
\end{abstract}

Keywords Cation exchange capacity; clay minerals; nutrient balance; phosphorus; soil fertility; x-ray diffractometry

\section{Introduction}

Organic farming systems are commonly briefly described as systems desisting from the use of mineral fertilisers and pesticides. This simple, operational definition is often used for public information. However, it has also been widely used in farming systems comparisons, on farm level (e.g. Lockeretz et al., 1980; Reganold et al., 1987; Schjønning et al., 2002) as well as in field experiments (e.g. Oehl et al., 2002;
Poutala et al., 1994). A far more comprehensive definition, emphasising the philosophical base of this farming system is given by Stockdale et al. (2001). Here, the term 'organic' is related to the concept of the farm as an organism, in which all components interact to create a coherent whole. International standards for organic farming are well established (IFOAM, 2002). Here, the farm organism concept is reflected in basic principles, followed by practical recommendations, basic standards and derogations. Soil nutrient concentrations are concerned in the basic principle stating that farmers should 'maintain and increase long-term fertility and biological activity of soils using locally adapted cultural, biological and mechanical methods as opposed to reliance on inputs'. In accordance with this objective, selfsufficiency is a central goal for many organic farmers, who try to minimise all kinds of purchased inputs to the farm. This management strategy may cause a decrease in available soil nutrient concentrations with time, as has been described for phosphorus (P) in a previous paper (Løes \& Øgaard, 2001). The decrease in available soil $\mathrm{P}$ found after long periods of organic farming raises the question if similar patterns can be found for potassium (K), the plant nutrient required by most crop species in the largest amounts next to nitrogen $(\mathrm{N})$. Nutrient balances are calculated as nutrient inputs (manure, seed, precipitation, etc.) minus nutrient outputs (yields, losses to water and air, etc.). A negative nutrient balance implies a deficit of the relevant nutrient, and a positive balance a surplus. For $\mathrm{K}$, a small average surplus on the farm level was found for organic dairy production in northern Europe (Watson et al., 2002). In Scandinavian studies, Kerner (1993) and Kristensen and Halberg (1995) found farm 
level surpluses of 10 and $33 \mathrm{~kg} \mathrm{~K} \mathrm{ha}{ }^{-1} \mathrm{y}^{-1}$ in Norway and Denmark, respectively. On the field level however, K-deficits seems to be the rule for organic dairy farming systems with moderate animal density, varying from -12 to $-73 \mathrm{~kg} \mathrm{ha}^{-1} \mathrm{y}^{-1}$ (Asdal \& Bakken, 1999; Askegaard \& Eriksen, 2000; Eltun et al., 2002). One reason for a larger deficit, or a decreased surplus, on the field level as compared to the farm level (Table 1) is internal nutrient losses from handling of fodder, manure, etc. Potassium is easily releasable and internal K-losses may be considerable, whereas $\mathrm{P}$ is less releasable with correspondingly smaller losses. In a farm level case study of self-sufficient combined organic beef and dairy production (Nolte \& Werner, 1994), only about $50 \%$ of the $\mathrm{K}$ in harvested fodder was recovered in manure ready for recycling to the soil. The internal losses comprised $78 \%$ of the total K-deficit of $65 \mathrm{~kg} \mathrm{ha}^{-1} \mathrm{y}^{-1}$, whereas the corresponding level for P was only $23 \%$ of a total deficit of $2.9 \mathrm{~kg}$ $\mathrm{P} \mathrm{ha}^{-1} \mathrm{y}^{-1}$. Hence, there seems to be a greater risk of losing $\mathrm{K}$ than $\mathrm{P}$ from livestock farming systems.

Soil K-concentrations have been shown to decrease during conversion (Aasbø et al., 1999; Løes \& Øgaard, 1997), but there is a need to study the temporal changes, as well as the levels of plant-available $\mathrm{K}$ after long-term organic dairy farming. The aim of the present paper is to report results from farm level studies of temporal changes in soil potassium. Further, we will discuss whether long-term organic dairy farming systems may become deficient in $\mathrm{K}$ when the farm management strategy is to minimise the amounts of purchased nutrients.

\section{Material and Methods}

\section{Participating farms}

On five organic dairy farms located in the southern part of Norway, agricultural soil was sampled twice over periods of 6-14 years (Table 2). Soil analyses from the first and second sampling were compared to assess changes in soil nutrient concentrations over time after conversion to organic dairy farming. At the second sampling, all the investigated farms had been organically managed for 9 years or more; one farm (Sletner) as long as since 1932. The farms vary with respect to farm size, climatic conditions, bedrock, and soil origin (Table 2). However, the soils were mainly light-textured on all farms, as only $23 \%$ of the samples had clay content between 25 and $40 \%$ (clay loam according to USDA, 1996), and no samples contained above $39 \%$ clay. On all farms the main income source is milk production. The animal density (number of dairy cows per hectare, Table 2) is relatively low, because all farmers strongly emphasise a high degree of self-sufficiency. Altogether, the farms constitute a fairly representative selection of southern Norwegian organic dairy farms with a high degree of selfsufficiency with nutrients. In comparison with other European countries, the size of farmland and herd on the studied farms is considerably lower. However, the farms are still representative of organic dairy farming systems where milk and meat are the main products sold, and only small amounts of fodder but no other nutrients are purchased.

Table $1 \mathrm{~K}$ and $\mathrm{P}$ balances $\left(\mathrm{kg} \mathrm{ha}^{-1} \mathrm{y}^{-1}\right)$ on farm and field level in organic dairy farming systems in northern Europe. Field level values are averages for most or the whole crop rotation (usually 6-7 years)

\begin{tabular}{|c|c|c|c|c|c|}
\hline \multicolumn{2}{|r|}{$K$} & \multicolumn{2}{|r|}{$P$} & \multirow[t]{2}{*}{ Country } & \multirow[t]{2}{*}{ Reference } \\
\hline Farm & Field & Farm & Field & & \\
\hline 14 & -130 & 4.5 & -8 & Norway & Løes et al., 1999 \\
\hline 0.5 & -29 & 3 & 0.5 & Sweden & Fagerberg et al., 1996 \\
\hline-7 & -36 & $\mathrm{~nm}^{*}$ & $\mathrm{~nm}^{*}$ & Germany & Mayer, 1997 \\
\hline-5 & -65 & -1.2 & -2.9 & Germany & Nolte and Werner, 1994 \\
\hline
\end{tabular}

${ }^{*}$ Note: $\mathrm{nm}=$ not measured. 
Table 2 General information on the five organic dairy farms

\begin{tabular}{|c|c|c|c|c|c|c|c|c|c|c|c|c|}
\hline Farm & Location & Alt & $A P$ & Land & Cows & Con & Bedrock & Deposits & Texture & $O M$ & Sampling & $n$ \\
\hline Nesset & $\begin{array}{l}61^{\circ} 40^{\prime} \mathrm{N} \\
11^{\circ} 10^{\prime} \mathrm{E}\end{array}$ & 333 & 485 & 8.0 & 8 & 1987 & Sparagmite & Glacifluvial & $\begin{array}{l}\text { Loamy sand, } \\
\text { sandy loam }\end{array}$ & L-M & 1989, 1998 & $18+3$ \\
\hline Brustad & $\begin{array}{l}60^{\circ} 10^{\prime} \mathrm{N} \\
11^{\circ} 50^{\prime} \mathrm{E}\end{array}$ & 170 & 709 & 7.5 & 10 & 1986 & $\begin{array}{l}\text { Precambrian } \\
\text { gneiss, granite }\end{array}$ & Marine & $\begin{array}{l}\text { Varied, loamy } \\
\text { sand - silty clay } \\
\text { loam }\end{array}$ & M & 1989, 1995 & $23+8$ \\
\hline Mogjerdet & $\begin{array}{l}63^{\circ} 40^{\prime} \mathrm{N} \\
08^{\circ} 55^{\prime} \mathrm{E}\end{array}$ & 30 & 1394 & 13.5 & 14 & 1984 & $\begin{array}{l}\text { Shale, gneiss } \\
\text { with mica }\end{array}$ & Fluvial & Loamy sand & L-M & 1990, 1998 & $27+7$ \\
\hline Alm & $\begin{array}{l}60^{\circ} 40^{\prime} \mathrm{N} \\
11^{\circ} 10^{\prime} \mathrm{E}\end{array}$ & 200 & 552 & 53.0 & 19 & 1979 & $\begin{array}{l}\text { Cambro-silurian } \\
\text { shale, limestone }\end{array}$ & Morainic & $\begin{array}{l}\text { Loam, } \\
\text { clay loam }\end{array}$ & $\mathrm{H}$ & 1989, 1997 & $82+20$ \\
\hline Sletner & $\begin{array}{l}59^{\circ} 53^{\prime} \mathrm{N} \\
11^{\circ} 20^{\prime} \mathrm{E}\end{array}$ & 138 & 782 & 8.5 & 7 & $1932^{\mathrm{a}}$ & $\begin{array}{l}\text { Precambrian } \\
\text { gneiss, granite }\end{array}$ & Marine & $\begin{array}{l}\text { Sandy loam, } \\
\text { silt loam }\end{array}$ & M & $\begin{array}{l}1983+1985 \\
1997\end{array}$ & $6+6$ \\
\hline
\end{tabular}

Location, north (N), east (E); altitude, $\mathrm{m}$ above sea level (Alt); annual precipitation, mm (AP); acreage of cultivated farmland, ha (Land); average number of milking cows; year of conversion (COn) defined as the first year no conventional fertilisers were used; description of local bedrock; description of soil origin (deposits); dominating oil mineral texture according to US-Soil-Taxonomy (USDA, 1996); dominating content of organic matter (OM) in topsoil according to Sveistrup (1984), abbreviated $\mathrm{L}=$ low $(0-3 \%), \mathrm{M}=$ medium $(3-6 \%)$ and $\mathrm{H}=$ high $(6-12 \%)$; Sampling years; number of soil samples at each sampling in topsoil + subsoil $(\mathrm{n})$.

asletner has been bio-dynamically managed since 1932, most probably the amounts of mineral fertilisers used before this year were negligible. 


\section{Farm conditions influencing K-balances and soil $\mathrm{K}$ concentrations}

For all farms except Sletner, farm level Kbalances ( $\mathrm{kg} \mathrm{K} \mathrm{ha}^{-1} \mathrm{y}^{-1}$ ) were calculated from farm accounts for 1 or more years at the beginning of the study period. For Sletner, the balance was based on personal records from the farmer. In general, there were small changes in the farming systems during the study period and hence the initial values were considered representative. The amounts of sold and purchased products were multiplied by K-concentrations as published in Ebbesvik (1997), and the difference between the sum of $\mathrm{K}$ in purchased and sold products constituted the farm level K-balance. Balances were adjusted for $\mathrm{K}$ input in precipitation and losses in runoff as appropriate (see below).

Due to the restricted amount of farmland, some concentrate was purchased on Nesset, Brustad and Mogjerdet and some forage on Sletner. Other input of $\mathrm{K}$ was by kalimagnesia $(24.5 \% \mathrm{~K})$ on two farms. On Mogjerdet, allowance had been given to use approximately 2 tonne kalimagnesia $\mathrm{y}^{-1}$, corresponding to on average $35 \mathrm{~kg} \mathrm{~K} \mathrm{ha}^{-1} \mathrm{y}^{-1}$. On Nesset, a total of $441 \mathrm{~kg} \mathrm{~K}$ as kalimagnesia was applied once on three fields in 1992. In the farm level Kbalance, this amount of $\mathrm{K}$ was averaged over the study period (9 years). Otherwise, no other purchased source of $\mathrm{K}$ such as, for example, conventional manure, rock powder, wood ash, etc., was used on any farm.

The K-inputs from precipitation and dry deposits in the districts where the five farms are located varied from 0.1 to $0.6 \mathrm{~kg} \mathrm{~K} \mathrm{ha}^{-1}$ $\mathrm{y}^{-1}$ for Nesset, Brustad, Alm and Sletner, whereas for Mogjerdet the average value was $2.2 \mathrm{~kg} \mathrm{~K} \mathrm{ha}{ }^{-1} \mathrm{y}^{-1}$ (Statens forurensningstilsyn, 1991, 1992). The K-input in precipitation was considered negligible except at Mogjerdet, where the input was included in the farm level $\mathrm{K}$-balance. Losses of $\mathrm{K}$ in runoff or drainage in a comparable organic dairy farming system with an average precipitation of $600 \mathrm{~mm} \mathrm{y}^{-1}$, recorded for 1991-1993, amounted to approximately $9 \mathrm{~kg} \mathrm{~K} \mathrm{ha}^{-1} \mathrm{y}^{-1}$ (Eltun et al., 1996). For Mogjerdet, this value may be too low an estimate because the annual precipitation is considerably higher (Table 2). The K-loss in drainage and runoff was therefore estimated at $9 \mathrm{~kg}$ $\mathrm{K} \mathrm{ha}^{-1} \mathrm{y}^{-1}$ for Nesset, Brustad, Alm and Sletner, and $50 \%$ higher, $13.5 \mathrm{~kg} \mathrm{~K} \mathrm{ha}^{-1} \mathrm{y}^{-1}$, for Mogjer- det. These values were included in the farm level K-balances.

On Alm, a lot of plant products were grown for sale and hence the fraction of fodder crops (mainly grass-clover ley) in the rotation was only approximately $40 \%$. For the other farms, the general crop rotation was grass-clover leys that were harvested for 3-4 years before ploughing, and then re-established with barley as a cover crop. On all farms, the available manure was generally distributed in small amounts to most fields each year, typically 1020 tonne ha ${ }^{-1} \mathrm{y}^{-1}$. On Nesset, Brustad, Alm and Sletner, the manure was divided into solid and liquid manure and the solid manure was stored outside with collection of drain water, whereas on Mogjerdet mixed slurry was stored in a covered tank. Lime was only applied at one farm, Nesset, during the study period.

\section{Soil sampling and analysis}

On all farms, cultivated topsoil $(0-20 \mathrm{~cm})$ and subsoil $(20-40 \mathrm{~cm})$ were sampled twice (Table 2). On Sletner, the initial sampling was a combined sampling from 1983 and 1985. On Mogjerdet, the samples were taken in early spring at both dates, and on Sletner, the initial samples were taken in early spring, whereas the second set of samples was taken in late autumn. On Nesset, Brustad and Alm, all sampling occurred in late autumn. To ensure that the sampled areas were the same at both times, the centre points of the sample areas were described on detailed maps on Nesset, Brustad, Mogjerdet and Alm. Each composite sample consisted of 10-12 soil cores, which were taken with an auger at a distance of $<5 \mathrm{~m}$ from the centre point. From the topsoil, one composite sample was taken per approximately 0.5 ha and from the subsoil, one per approximately 2 ha, with a corresponding topsoil sample. On Sletner, the first sampling occurred as composite samples of 10-12 soil cores that were spread over each of the six largest fields of the farm. To assess the influence of the sampling method, in 1997 the sampling method from the first sampling was repeated in addition to a sampling as described for the other farms. Because the field size on Sletner is small $(<1 \mathrm{ha})$, the sampling method did not influence the results notably, except the K-AL values (see Results).

In all soil samples, ammonium-acetate lactate 
(Egnér et al., 1960) extractable concentrations of $\mathrm{K}$, magnesium $(\mathrm{Mg})$, calcium $(\mathrm{Ca})$, sodium $(\mathrm{Na})$ and $\mathrm{P}$ were measured by ICP (inductive coupled plasma analysis). The first set of samples from Sletner is an exception. Here, no $\mathrm{Na}$ concentrations were measured, other cation concentrations were measured by atomic absorption and $\mathrm{P}$ was measured colorimetrically. $\mathrm{K}, \mathrm{Ca}$ and $\mathrm{Mg}-\mathrm{AL}$ values are generally not influenced by the method of measurements; for P, see Løes and Øgaard (2001). Concentrations of AL-extractable nutrients are abbreviated as K-AL, etc. Because plants utilise Kfractions that are not initially AL-extractable, acid-soluble $\mathrm{K}$ was also measured. The soil sample (ratio of soil to solution of 1:10) was boiled for $10 \mathrm{~min}$ in $1 \mathrm{M}$ nitric acid (Pratt, 1965, slightly modified). After filtration the Kconcentration in the extract was measured by atomic absorption. The K-AL value was subtracted from the $\mathrm{K}-\mathrm{HNO}_{3}$ value because some of the $\mathrm{K}$ extracted by nitric acid will also be soluble in AL-solution. The $\mathrm{K}-\mathrm{HNO}_{3}$ minus the $\mathrm{K}-\mathrm{AL}$ value is further called acid-soluble $\mathrm{K}$. Acid-soluble $\mathrm{K}$ was measured on a subset of samples consisting of all subsoil and the corresponding topsoil samples. The particle-size distribution of mineral material $<2 \mathrm{~mm}$ was determined in this subset by the pipette method (Elonen, 1971). For the first combined set of samples from Sletner, K-AL, P-AL and $\mathrm{pH}$ was analysed in samples from 1985, whereas all other analyses were conducted in samples from 1983.

For all soil samples, $\mathrm{pH}\left(\mathrm{H}_{2} \mathrm{O}, \mathrm{v} / \mathrm{v}\right.$ soil/water $1 / 2.5$ ) was measured. Further, total $C$ (tot-C) and total $\mathrm{N}$ (tot- $\mathrm{N}$ ) were measured in all samples, except from the initial subsoil samples from Sletner, where only total $\mathrm{N}$ was analysed. Tot- $\mathrm{N}$ and tot- $\mathrm{C}$ were determined by dry combustion $>1000^{\circ} \mathrm{C}$ in a Perkin Elmer 2400 analyser. The soil content of organic matter was calculated as tot-C multiplied by 2.0 (Schachtschabel et al., 1998). For soil samples with $\mathrm{pH}>6.5$ from Alm (cambro-silurian bedrock), the content of organic $\mathrm{C}$ also was measured by dry combustion $\left(1600^{\circ} \mathrm{C}\right.$, Leco EC12) after possible soil carbonates in crushed soil samples had been dissolved in $2 \mathrm{~N}$ hydrochloric acid $(\mathrm{HCl})$. Generally, the differences between tot- $\mathrm{C}$ values measured with and without $\mathrm{HCl}$-washing were negligible.

The mineralogical composition of two subsoil samples from each farm was investigated by $X$ - ray diffractometry (XRD). Subsoil samples were used to avoid having too much organic matter in the samples, because removing organic matter may partly destroy the soil minerals. The mineral composition was assumed to be sufficiently equal in topsoil and subsoil for our purpose. A Philips PW 1710 diffractometer with $\mathrm{Cu}$ radiation, graphite monochromator and $1^{\circ}$ divergence slit was used for analysis. Four particle fractions, $<0.002 \mathrm{~mm}$ (clay), 0.002-0.006 $\mathrm{mm}$ (fine silt), $0.006-0.06 \mathrm{~mm}$ (medium and coarse silt) and 0.06-2 $\mathrm{mm}$ (sand), were separated by sedimentation and sieving, and subsequently crushed before XRD. The X-ray mounts for the different fractions were prepared by filtering on to a ceramic filter and drying at room temperature. The clay film was also treated with ethylene glycol and heated at 300 and $500^{\circ} \mathrm{C}$ for $1 \mathrm{~h}$. Mineral identifications were carried out following Brown (1961). The semi-quantitative determination of minerals was based on measured intensities calculated from peak heights on the XRD diffractograms compared to intensities measured on pure minerals (Gjems, 1967).

For each farm, a set of comparison soil Kvalues was achieved from the Agricultural Service Laboratory of the Norwegian Centre for Soil and Environmental Research, Ås. These data were average soil K-values from conventional animal husbandry farms with the same main mineral soil texture in the same district as the respective organic farm. For Sletner, some conventional stockless farms were included in the acid-soluble $\mathrm{K}$ value, to ensure a significant amount of samples.

\section{Calculation of exchangeable cations}

An estimated cation-exchange capacity (CEC, $\mathrm{mEq}$ cations $\mathrm{kg}^{-1}$ soil) was achieved by a simple transformation of AL-extractable cations, in addition to $\mathrm{H}$-ions estimated from soil $\mathrm{pH}$. The AL-method often induces ion concentrations that come close to the standard method of determining exchangeable cations in soil, extraction with ammonium acetate, $\mathrm{NH}_{4} \mathrm{OAc}$ (Thomas, 1982). Exchangeable cations (abbreviated K-Ac, etc.) were estimated by regression equations found by comparing ALand $\mathrm{NH}_{4} \mathrm{OAc}$-extractable concentrations of cations in 77 Norwegian samples of various cultivated soils. These samples were taken from 23 
experimental fields located in different parts of Norway (A.F. Øgaard, Department of Soil and Water Science, the Agricultural University of Norway, unpublished data). The regression equations and proportion of variability explained by each model ( $\mathrm{R}^{2}$ values) are as follows: $\mathrm{Na}-\mathrm{Ac}=1.08^{*} \mathrm{Na}-\mathrm{AL}-0.64\left(\mathrm{R}^{2}=0.48\right)$; $\mathrm{K}-\mathrm{Ac}=0.98^{*} \mathrm{~K}-\mathrm{AL}-1.80\left(\mathrm{R}^{2}=0.92\right) ; \mathrm{Mg}-\mathrm{Ac}$ $=0.90^{*} \mathrm{Mg}-\mathrm{AL}-0.30\left(\mathrm{R}^{2}=0.97\right) ; \mathrm{Ca}-\mathrm{Ac}=0.99^{*}$ Ca-AL + $6.22\left(\mathrm{R}^{2}=0.90\right) ; \mathrm{H}-\mathrm{Ac}=-5.87^{*} \mathrm{pH}+$ $44.23\left(\mathrm{R}^{2}=0.73\right)$. CEC is the sum of all exchangeable cations measured in $\mathrm{mg} \mathrm{kg}^{-1}$ soil, each cation divided by the atomic weight and multiplied by the valence. As only $10 \%$ of the soil samples had $\mathrm{pH}<5.5$, we did not distinguish between potential and effective CEC. For Sletner, no CEC-calculation could be done due to missing values for $\mathrm{Na}$.

\section{Statistical analysis}

To test if the changes in soil nutrient concentrations over time were statistically significant, we compared the results from the first sampling to the results from the second sampling by a paired two-sided $t$-test (SAS Institute, 1987). This was done for topsoil and subsoil samples within each farm. Interesting relationships between parameters were investigated by regression analysis (Minitab software).

\section{Results and Discussion}

\section{Farm level K-balances}

On Alm, a deficit of $-15 \mathrm{~kg} \mathrm{~K} \mathrm{ha}^{-1} \mathrm{y}^{-1}$ was calculated, and on Brustad, the balance was zero. On Nesset and Sletner, surpluses of 27 and $29 \mathrm{~kg} \mathrm{~K} \mathrm{ha}{ }^{-1} \mathrm{y}^{-1}$ were found due to purchased fodder, whereas on Mogjerdet the surplus was $32 \mathrm{~K} \mathrm{~kg} \mathrm{ha}^{-1} \mathrm{y}^{-1}$ due to purchased fertiliser. The values on Nesset, Sletner and Mogjerdet were comparable to the values found in other studies (Table 1; Kerner, 1993; Kristensen \& Halberg, 1995), whereas the values for Alm and Brustad were lower. Field level balances of $\mathrm{K}$ for each farm were not measured, but by comparison with the studies referred to in Table 1 , it is very probable that the average field level $\mathrm{K}$-balance is negative. The corresponding farm level P-balances for Alm, Brustad, Nesset, Sletner and Mogjerdet were -3, 1,
7,12 and $2 \mathrm{~kg} \mathrm{ha}^{-1} \mathrm{y}^{-1}$, respectively (Løes \& Øgaard, 2001). We assume that there were field level P-deficits on Alm, Brustad and Mogjerdet. The farm level K-balances and P-balances were well correlated, as was also shown for 12 farms in conversion to organic farming (Løes \& Øgaard, 1997).

\section{Changes and levels of soil K- concentrations}

\section{$K-A L$}

From the first to the second soil sampling, the K-AL concentration did not decrease significantly on any farm in either topsoil or subsoil (Table 3). This is different from the pattern for the corresponding P-AL concentrations, where a statistically significant decrease in topsoil occurred on all farms (Løes \& Øgaard, 2001). The largest average decrease was found on Mogjerdet with the highest initial concentration. Here, the average P-AL value decreased from 140 to $119 \mathrm{mg} \mathrm{P} \mathrm{kg}{ }^{-1}$ soil, whereas on the farms with the lowest initial P-AL concentrations, the average values decreased only from 57 to 50 (Brustad) and from 57 to $45 \mathrm{mg}$ $\mathrm{P} \mathrm{kg}^{-1}$ soil (Sletner). A likely reason for decrease in topsoil P-AL, but not in K-AL concentrations, is that the P-AL values adapt more slowly to changes in field level nutrient balances, so that the values decrease during a longer period.

A significant increase in topsoil K-AL was found on Nesset, and in both topsoil and subsoil on Sletner. The increase in topsoil K-AL on Nesset cannot be related to the applied kalimagnesia because the amount of $\mathrm{K}$ was only $12 \mathrm{~kg} \mathrm{ha}^{-1}$ applied once, which would hardly influence the soil K-AL significantly 6 years after application. The increase in K-AL on Nesset is difficult to explain. The increase in topsoil $\mathrm{K}-\mathrm{AL}$ found on Sletner is uncertain, because the average K-AL value in soil samples taken all over the fields (Table 3) was higher than in samples taken around the centre points. In topsoil, the value was $154 \mathrm{mg} \mathrm{K} \mathrm{kg}^{-1}$ soil compared to 101 and in subsoil 80 compared to 66, respectively.

As shown in Table 2, the topsoil K-AL values on Nesset, Mogjerdet and Sletner were comparable to conventional topsoil values, but on Alm and Brustad, the values were well below conventional values. The average K-AL level in 
Table 3 Average, minimum and maximum value and standard error (s.e.) of the mean for topsoil $(0-20 \mathrm{~cm})$ and subsoil $(20-40 \mathrm{~cm}) \mathrm{K}-\mathrm{AL}$ concentrations on five organic dairy farms at two sampling dates (first and second), as compared to topsoil data from conventional farms in the same district. All values $\mathrm{mg} \mathrm{kg}^{-1} \mathrm{dry} \mathrm{soil}$

\begin{tabular}{|c|c|c|c|c|c|}
\hline \multirow[t]{2}{*}{ Farm } & \multicolumn{2}{|c|}{ Topsoil } & \multirow{2}{*}{$\begin{array}{l}\text { Conventional } \\
\text { Mean }\end{array}$} & \multicolumn{2}{|c|}{ Subsoil } \\
\hline & Mean (min-max) & s.e. & & Mean (min-max) & s.e. \\
\hline \multicolumn{6}{|l|}{ Nesset } \\
\hline First & $59(28-136)$ & 6 & & $38(30-47)$ & 5 \\
\hline Second & $80(42-173)^{*}$ & 7 & 82 & $60(49-80)$ & 1 \\
\hline$n$ & 21 & & 183 & 3 & \\
\hline \multicolumn{6}{|l|}{ Brustad } \\
\hline First & $76(30-213)$ & 10 & & $49(14-92)$ & 1 \\
\hline Second & 72 (38-191) & 7 & 135 & $47(22-81)$ & 8 \\
\hline$n$ & 23 & & 215 & 8 & \\
\hline \multicolumn{6}{|c|}{ Mogjerdet } \\
\hline First & $107(50-181)$ & 6 & & $80(41-181)$ & 18 \\
\hline Second & $93(51-174)$ & 6 & 93 & 52 (37-91) & 7 \\
\hline$n$ & 27 & & 1085 & 7 & \\
\hline \multicolumn{6}{|l|}{ Alm } \\
\hline First & $78(31-228)$ & 5 & & $38(6-72)$ & 4 \\
\hline Second & 77 (33-199) & 4 & 110 & $41(21-78)$ & 3 \\
\hline$n$ & 82 & & 474 & 20 & \\
\hline \multicolumn{6}{|l|}{ Sletner } \\
\hline First & $97(54-130)$ & 11 & & $42(25-74)$ & 8 \\
\hline Second & $154(75-215)^{*}$ & 20 & 148 & $80(60-109)^{*}$ & 7 \\
\hline$n$ & 6 & & 595 & 6 & \\
\hline
\end{tabular}

Soil K-AL concentrations are marked grey when the average change was statistically significant. Number of soil samples = $n$. Level of significance is abbreviated * for $0.01<p<0.05$.

topsoil at the second sampling was classified as medium high (65-155 $\mathrm{mg} \mathrm{K} \mathrm{kg}^{-1}$ soil) for all the organic dairy farms. However, the fraction of topsoil samples low in K-AL $(<65)$ at the second sampling was 33, 38, 26, 45 and $26 \%$, respectively, for Nesset, Brustad, Mogjerdet, Alm and Sletner. This indicates that suboptimal K-supply may influence plant growth on certain fields on all farms, especially with dry weather. The subsoil concentrations of K-AL were generally well below topsoil values, and do not indicate large potentials of K-supply by deep root growth.

All fields were sampled on both sampling dates, the crop rotations were not substantially changed during the period of the study, and the manure was generally distributed in small amounts to most fields each year (typically 1020 tonne ha ${ }^{-1} \mathrm{y}^{-1}$ ). Hence, we assume that the effects of crop rotation and manure distribution on soil nutrient concentrations were eliminated by the calculation of average K-AL values. As the distance between the farms was large and the local climate considerably different (Table
$2)$, the effect of weather conditions due to different sampling years and different time of the year for the material as a whole was most likely not substantial.

\section{Acid-soluble $K$}

A significant decrease in the average value of acid-soluble $\mathrm{K}$ was found in both top- and subsoil on one farm, Alm (Table 4). The decrease tended to be greater when the initial level of acid-soluble $\mathrm{K}$ was higher (Figure 1, $\mathrm{R}^{2}$ $=0.39$ ), a pattern that was also found for the soil P-AL concentrations (Løes \& Øgaard, 2001). For an average dry bulk density of 1.20 $\mathrm{kg}$ dry soil $\mathrm{dm}^{-3}$ in the 0-40 $\mathrm{cm}$ layer (Riley, 1996) the decrease in acid-soluble $K$ found on Alm farm amounts to $240 \mathrm{~kg} \mathrm{~K}^{-1}$ from 1989 to 1997 , or $30 \mathrm{~kg} \mathrm{~K} \mathrm{ha}{ }^{-1} \mathrm{y}^{-1}$. There was no significant decrease in acid-soluble $K$ values on the other farms. However, there was a large decrease in the average value of acid-soluble $\mathrm{K}$ on Mogjerdet, but the number of soil samples analysed for acid-soluble $\mathrm{K}$ was low (Tables 3 and 4) and the variability of the data was high, 
Table 4 Average, minimum and maximum value and standard error (s.e.) of the mean of topsoil $(0-20 \mathrm{~cm})$ and subsoil $(20-40 \mathrm{~cm})$ concentrations of acid-soluble $\mathrm{K}\left(\mathrm{K}-\mathrm{HNO}_{3}\right.$ minus $\left.\mathrm{K}-\mathrm{AL}\right)$ on five organic dairy farms at two sampling dates (first and second), as compared with topsoil data from conventional farms in the same district. All values $\mathrm{mg} \mathrm{kg}^{-1}$ dry soil

\begin{tabular}{|c|c|c|c|c|c|}
\hline \multirow[t]{2}{*}{ Farm } & \multicolumn{2}{|c|}{ Topsoil } & \multirow{2}{*}{$\frac{\text { Conventional }}{\text { Mean }}$} & \multicolumn{2}{|c|}{ Subsoil } \\
\hline & Mean (min-max) & s.e. & & Mean (min-max) & s.e. \\
\hline \multicolumn{6}{|l|}{ Nesset } \\
\hline First & $291(247-345)$ & 29 & & $293(243-334)$ & 27 \\
\hline Second & $302(258-342)$ & 24 & 407 & $278(221-351$ & 38 \\
\hline$n$ & 3 & & 10 & 3 & \\
\hline \multicolumn{6}{|l|}{ Brustad } \\
\hline First & $243 \quad(68-353)$ & 35 & & 518 (158-1196) & 137 \\
\hline Second & $296(140-453)$ & 44 & 385 & 500 (197-949) & 113 \\
\hline$n$ & 8 & & 12 & 8 & \\
\hline \multicolumn{6}{|c|}{ Mogjerdet } \\
\hline First & 557 (346-856) & 66 & & 693 (515-1114) & 87 \\
\hline Second & $431(281-499)$ & 28 & 608 & $562(434-674)$ & 34 \\
\hline$n$ & 7 & & 443 & 7 & \\
\hline \multicolumn{6}{|l|}{ Alm } \\
\hline First & 402 (161-689) & 32 & & $350(110-760)$ & 37 \\
\hline Second & $351(132-642)^{* * *}$ & 29 & 213 & $287(110-510)^{*}$ & 25 \\
\hline$n$ & 20 & & 18 & 20 & \\
\hline \multicolumn{6}{|l|}{ Sletner } \\
\hline First & $365(241-620)$ & 62 & & not measured & \\
\hline Second & $401(209-774)$ & 97 & 454 & 397 (203-822) & 109 \\
\hline$n$ & 6 & & 16 & 6 & \\
\hline
\end{tabular}

Soil concentrations of acid-soluble $\mathrm{K}$ are marked grey when the average change was statistically significant. Number of soil samples $=n$. Levels of significance are abbreviated ${ }^{*}$ for $0.01<p<0.05$ and ${ }^{* * *}$ for $p<0.001$.

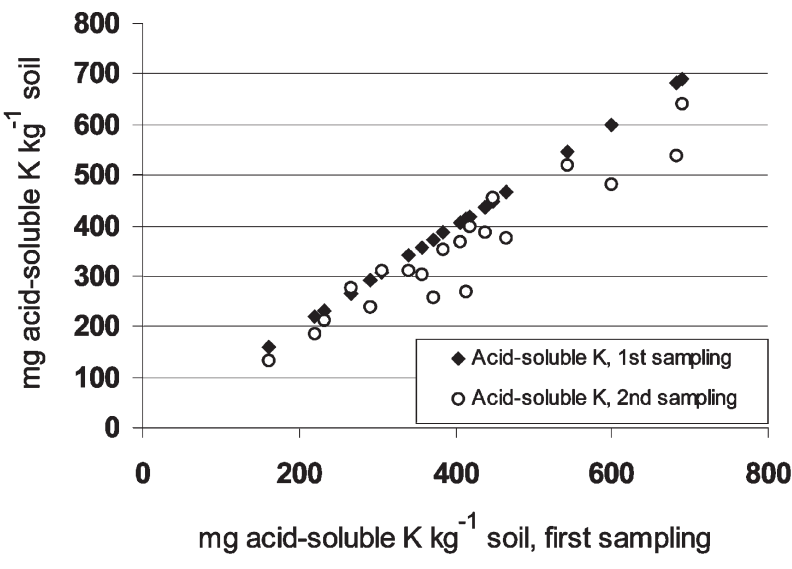

Figure 1 The decrease in acid-soluble $\mathrm{K}$ (K-HNO3 minus $\mathrm{K}-\mathrm{AL})$ in topsoil $(0-20 \mathrm{~cm})$ on the farm Alm, shown as the relation between acid-soluble $\mathrm{K}$ concentrations for paired samples from the first and second sampling. The samples have been arranged by increasing concentrations of acidsoluble $\mathrm{K}$ at the first sampling. so that statistically significant results were not obtained. Compared with conventional topsoil values, the level of acid-soluble $\mathrm{K}$ at the second sampling was lower on all farms except Alm. At the second sampling, the average topsoil concentrations of acid-soluble $\mathrm{K}$ were in the lower part of the medium class (300-800 mg K $\mathrm{kg}^{-1}$ soil) or they were low $(<300)$ on all the organic farms. The fraction of topsoil samples with low values of acid-soluble $\mathrm{K}$ was 67 , 63, 14, 25 and 44\%, respectively, on Nesset, Brustad, Mogjerdet, Alm and Sletner. This shows that on most farms, there are no large reserves in the soils of the $\mathrm{K}$ - fraction that may replenish the K-AL removed by plant uptake. On Mogjerdet, the reserves are somewhat larger.

The subsoil concentrations of acid-soluble $\mathrm{K}$ were comparable to the topsoil concentrations on Nesset, Alm and Sletner, and somewhat higher than the topsoil concentrations on Brustad and Mogjerdet. This pattern is opposite to that of K-AL, where the subsoil concentrations 
were lower than in topsoil. One reason for this is probably that the K-AL value is more closely linked to the soil content of organic matter, whereas the acid-soluble $\mathrm{K}$ value is more influenced by soil mineral composition. A positive correlation was found between topsoil K-AL and tot-C $(p<0.05)$, but not for acid-soluble K.

\section{Minimum level of soil $\mathrm{K}$}

$\mathrm{K}$-depletion will decrease the soil K-AL concentration until a certain minimum level is reached, which varies between different soil types (topsoil $\mathrm{K}-\mathrm{AL}_{\min }=0.94^{*}($ silt $\%+$ clay\%) +13.08 , Øgaard etal., 2002). This minimum level of K-AL is not absolute, as a long-lasting depletion will probably give a further slight decrease. However, for agricultural purpose, this minimum level can be used as a threshold value to assess if extensive $\mathrm{K}$-depletion, causing $\mathrm{K}-\mathrm{AL}$ values below the minimum level, has occurred. K-AL values close to the minimum level show that net release from this fraction is not to be expected. Following the formula above, average values of $\mathrm{K}-\mathrm{AL}_{\min }$ in topsoil were 71 on Nesset, 74 on Brustad, 49 on Mogjerdet, 72 on Alm and 74 on Sletner. Hence, for Nesset, Brustad and Alm the average topsoil $\mathrm{K}-\mathrm{AL}$ concentration (Table 3) is approaching the minimum level for the soil. On Mogjerdet and Sletner, the topsoil still has the potential to supply $\mathrm{K}$ from the K-AL fraction. In addition, $\mathrm{K}$-release from reserve $\mathrm{K}$ may still occur on all farms.

\section{Soil K-concentrations and K-balances}

Because on average there probably was a Kdeficit on the field level in this study, significant decreases in soil $\mathrm{K}$ concentrations could have been expected. With a K-deficit of $47 \mathrm{~kg} \mathrm{ha}^{-1}$ $\mathrm{y}^{-1}$, Aasbø et al. (1999) found a decrease in KAL from 90 to 78 and in acid-soluble $\mathrm{K}$ from 587 to $500 \mathrm{mg} \mathrm{K} \mathrm{kg}^{-1}$ soil over 7 years. A comparable decrease in topsoil K-AL, from 141 to $117 \mathrm{mg} \mathrm{kg}^{-1}$ soil over 6 years, was found by Løes and Øgaard (1997). However, both these studies were done on systems in the process of conversion to organic farming, where the initial soil K-concentrations were higher than in the present study. With lower initial soil K-concentrations, K-AL decreases will not be revealed as easily because a minimum $\mathrm{K}-\mathrm{AL}$ level is approached, where further changes will occur slowly (Øgaard et al., 2002). Furthermore, soil concentrations of $\mathrm{K}-\mathrm{AL}$ are subject to rapid and large variations due to crop rotation and fertilisation, as shown by Björklund and Salomon (1995), where an initial value of $180 \mathrm{mg}$ $\mathrm{K}-\mathrm{AL} \mathrm{kg}^{-1}$ soil was reduced to 55 during three seasons of ley harvest without manure application. This demonstrates the dynamic nature of this soil characteristic. The K-AL value is rapidly adapted to changes in the K-balance, and this may explain why significant changes, that were found for P-AL, were mostly not found in the present study. With respect to acid-soluble $\mathrm{K}$, this characteristic is less subject to rapid changes, but the low number of samples may have restricted the possibility of finding significant changes.

\section{Exchangeable cations and K-fraction of basic cations}

Soil K-depletion may increase the soil cation exchange capacity (Nielsen \& Møberg, 1984), due to increased content of expanded clay minerals. Hence, it was of interest to study whether CEC had changed from the first to the second sampling. However, changes in the soil content of organic matter (= total $\mathrm{C}$ multiplied by 2 , see Materials and Methods) will also affect CEC changes, because increase in soil organic matter will increase the CEC. Averaged over all farms, the CEC was quite closely related to the soil content of total C $\left(\mathrm{R}^{2}=69 \%\right.$ for topsoil and $43 \%$ for subsoil, second sampling). Hence the changes in CEC values must be related to the changes in soil content of tot- $C$, to assess whether they only reflect changes in soil content of organic matter or may in fact be indicative of soil K-depletion. The most important basic cations, $\mathrm{Mg}$ and $\mathrm{Ca}$, as well as soil $\mathrm{pH}$ and tot-C are shown in Table 5 . Mg-AL values were classified as very high or high $(>90$ or $60-90 \mathrm{mg} \mathrm{Mg} \mathrm{kg}{ }^{-1}$ soil) except from in the subsoil at Mogjerdet where it was was low $(<25)$ at the second sampling. At Alm, the CaAL concentrations were extremely high, most probably due to the cambro-silurian bedrock. Elsewhere the Ca-AL levels were high (1001$2000 \mathrm{mg} \mathrm{Ca} \mathrm{kg}{ }^{-1}$ soil) or medium high (501$1000)$ in topsoil, and medium high or low $(<500)$ in subsoil.

Although the period between the sampling dates was short, a significant increase in CEC 
Table 5 Average values of topsoil $(0-20 \mathrm{~cm})$ and subsoil $(20-40 \mathrm{~cm}) \mathrm{pH}$ and concentrations of $\mathrm{Mg}-\mathrm{AL}, \mathrm{Ca}-\mathrm{AL}$, total $\mathrm{N}$ and total $\mathrm{C}$ on five organic dairy farms at two sampling dates (first and second)

\begin{tabular}{|c|c|c|c|c|}
\hline Farm & $p H$ & $\begin{array}{cc}M g-A L & C a-A L \\
m g ~ k g^{-1} & \text { soil }\end{array}$ & $\stackrel{\text { Tot }-N}{-} \%$ Tot-C & $\begin{array}{l}C E C \\
m E q k^{-1} \text { soil }\end{array}$ \\
\hline
\end{tabular}

\begin{tabular}{lllllll}
\hline Topsoil & & & & & \\
Nesset, First & 5.8 & 78 & 633 & 0.15 & 2.4 & 152 \\
Nesset, Second & $6.3^{* * *}$ & $90\left(^{*}\right)$ & 761 & 0.08 & 1.8 & $136^{* * *}$ \\
Brustad, First & 5.9 & 74 & 761 & 0.18 & 2.9 & 154 \\
Brustad, Second & $5.7^{* * *}$ & 80 & $663^{*}$ & $0.16^{* * *}$ & $2.6^{* *}$ & $162^{* * *}$ \\
Mogjerdet, First & 6.3 & 57 & 774 & 0.13 & 1.9 & 134 \\
Mogjerdet, Second & $6.0^{* * *}$ & $49\left(^{*}\right)$ & 839 & 0.15 & 2.1 & $151^{* * *}$ \\
Alm, First & 6.5 & 114 & 4509 & 0.44 & 5.2 & 311 \\
Alm, Second & $6.3^{* * *}$ & $93^{* * *}$ & 4340 & 0.45 & 5.1 & 311 \\
Sletner, First & 6.3 & 75 & not measured & 0.29 & 3.0 & not measured \\
Sletner, Second & 6.3 & $94^{*}$ & 1393 & $0.20^{* * *}$ & 2.8 & not measured \\
Subsoil & & & & & 113 \\
Nesset, First & 6.2 & 35 & 305 & 0.02 & 0.4 & 117 \\
Nesset, Second & 6.5 & 69 & $704\left(^{*}\right)$ & $0.05^{*}$ & $0.9\left(^{*}\right)$ & 135 \\
Brustad, First & 5.9 & 90 & 336 & 0.04 & 0.7 & $147\left(^{*}\right)$ \\
Brustad, Second & 5.8 & 116 & 397 & 0.05 & $1.0\left(^{*}\right)$ & 122 \\
Mogjerdet, First & 6.2 & 40 & 559 & 0.08 & 1.2 & 120 \\
Mogjerdet, Second & 6.1 & $19^{*}$ & $317\left(^{*}\right)$ & 0.05 & $0.6\left(^{*}\right)$ & 494 \\
Alm, First & 6.6 & 116 & 7544 & 0.45 & 6.6 & 320 \\
Alm, Second & 6.4 & $73^{* *}$ & 4637 & 0.34 & $4.1\left(^{*}\right)$ & not measured \\
Sletner, First & 6.3 & not measured & not measured & 0.21 & not measured \\
Sletner, Second & 6.3 & 75 & 1046 & $0.15^{* * *}$ & 2.2 & not measured \\
\hline
\end{tabular}

Soil $\mathrm{pH}$ and nutrient concentrations are marked grey when the average change was statistically significant. Levels of significance are abbreviated $\left(^{*}\right)$ for $p<0.1,{ }^{*}$ for $p<0.05,{ }^{* *}$ for $p<0.01$ and ${ }^{* * *}$ for $p<0.001$.

was found in topsoil and subsoil on Brustad, and in topsoil on Mogjerdet, whereas on Nesset, the CEC value in topsoil decreased. Because the content of tot- $C$ in topsoil on Brustad was found to decrease (Table 5), a corresponding decrease in topsoil CEC would have been expected. Hence, on this farm the increase in topsoil CEC may well be an indication of Kdepletion. In subsoil on Brustad, we found a parallel increase in soil total $\mathrm{C}$ content and CEC. The increase in topsoil CEC on Mogjerdet cannot be explained by an increase in soil organic matter, and may also be an indication of K-depletion, despite a small but regular use of kalimagnesia on this farm. In a study of two Danish soils, CEC was found to increase after long-term K-depletion, from 96 to 104 and from 100 to $112 \mathrm{mEq} \mathrm{kg}{ }^{-1}$ soil (Nielsen and Møberg, 1984). These values correspond well with the changes found in topsoil on Mogjerdet and
Brustad. However, the period of depletion was much longer than the periods studied here.

The K-fraction of the sum of exchangeable bases $(\mathrm{Na}, \mathrm{K}, \mathrm{Ca}$ and $\mathrm{Mg}$ ) was quite similar in the top- and subsoil within each farm. The fraction was 2-4\% on Nesset, Brustad and Mogjerdet, and $<1 \%$ on Alm. In the US, when the K-fraction is $<2 \%$ of the sum of exchangeable bases (SEB) and the SEB is $<100 \mathrm{mEq} \mathrm{kg}{ }^{-1}$ soil, the soil is defined as causing constraints on plant growth due to K stress (Sharpley and Buol, 1987). On Alm, the SEB was approximately $240 \mathrm{mEq} \mathrm{kg}{ }^{-1}$ soil because of the extraordinarily high contents of $\mathrm{Ca}$ and $\mathrm{Mg}$ and the criteria described by Sharpley and Buol is not fulfilled. However, for Nesset, Brustad and Mogjerdet, the SEB was between 22 and 51 $\mathrm{mEq} \mathrm{kg}^{-1}$ soil, and with the K-fraction close to $2 \%$ this indicates that the K-availability of the soil is approaching a critical level. 


\section{Soil mineral composition}

Illite and mixed layer minerals are the most important soil mineral K-sources. Weighted averages of clay, silt and sand fractions showed that none of the soil samples contained more than $6 \%$ illite, and only one contained mixed layer minerals, in a very low amount (Table 6). Not surprisingly, as biotite (trioctaedric) is rapidly weathered, the illite was generally dioctaedric. Indications of biotite were found only in the coarse silt and sand fraction of one soil sample from Nesset and in the fine silt fraction of one sample from Sletner. The average vermiculite content varied from 1 to $3 \%$; in the clay fraction it varied from 3 to $11 \%$. No smectite was found. The content of K-feldspar varied only from 8 to $13 \%$, and other silicate minerals (plagioclase, quartz) were the dominating soil minerals. On Mogjerdet, the content of amphibolite was high, and on Alm, one sample had a large content of carbonate, which is reasonable because the farm lies in a cambrosilurian area. The carbonate content was especially high in the sand and coarse silt fraction (30 and 20\%, respectively).

When soils are depleted of $K$, the content of illite has been shown to be reduced (Leinweber et al., 1991; Møberg \& Nielsen, 1983) due to Kremoval from interlayers of illitic minerals. With prolonged depletion, vermiculite and eventually smectite may be produced (Møberg \& Nielsen, 1983; Niederbudde et al., 1989; Tributh et al., 1987). In the present study, the period between the soil samplings was too short to reveal if the illite content had decreased with time.

\section{Soil K-concentrations and farm management}

There seems to be a serious risk of $\mathrm{K}$ deficiency on most of the farms studied here. No severe symptoms of plant deficiency have been reported by farmers or farm visitors, and there was no general decrease in soil $\mathrm{K}$-concentrations except in acid-soluble $\mathrm{K}$ on one farm. However, the soil K-levels were generally medium to low, and were low in a large fraction of the topsoil samples on most farms. Furthermore, the average K-AL level was quite close to the minimum level for K-AL, showing that net K-release from this fraction is low. The changes in soil CEC seem to substantiate the pattern of soil K-depletion, and on most farms, the K-saturation indicated that the K-availability was approaching a critical level. The studies of soil mineralogy did not reveal large amounts of K-releasing minerals in these soils. Hence, it is probable that the yield levels are already limited by the K-supply, at least on some fields, with K-demanding crops and/or with dry weather. By dry conditions, the transport of $\mathrm{K}$ to roots is reduced due to a low water content in soil. K-deficiency will reduce yield levels before deficiency symptoms can be seen (Martin \& Matocha, 1973).

It seems probable that on the farms studied here, the K-availability will be reduced to such an extent that yields and crop quality will decrease, if no changes are introduced in the farm management. It is also very likely that nitrogen fixation by red clover, an essential ley legume in organic farming, may be hampered because it competes less efficiently for $K$ than

Table 6 Content of minerals in subsoil $(20-40 \mathrm{~cm})$ on five organic dairy farms at the second sampling, weighted average of four mineral soil fractions $<2 \mathrm{~mm}$

\begin{tabular}{|c|c|c|c|c|c|c|c|c|c|}
\hline Farm & Quarts & $\begin{array}{l}\text { K-feld } \\
\text { spar }\end{array}$ & $\begin{array}{l}\text { Plagio } \\
\text { clase }\end{array}$ & Amphibolite & Carbonate & Illite & Chlorite & Vermiculite & $\begin{array}{l}\text { Mixed } \\
\text { layer } \\
\text { minerals }\end{array}$ \\
\hline Nesset & 54 & 9 & 26 & 4 & 0 & $3(6)$ & 2 & 2 & 0 \\
\hline Alm, a & 56 & 11 & 27 & 0 & 0 & $4(8)$ & 1 & 2 & 0 \\
\hline Alm, b & 41 & 11 & 19 & 0 & 23 & $6(11)$ & 0 & 0 & 1 \\
\hline Brustad & 50 & 13 & 32 & 2 & 0 & $3(11,3)$ & 1 & 1 & 0 \\
\hline Mogjerdet & 34 & 8 & 42 & 10 & 0 & 1 (3) & 2 & 3 & 0 \\
\hline Sletner & 42 & 12 & 37 & 4 & 0 & $2(4)$ & 1 & 2 & 0 \\
\hline
\end{tabular}

All values in \%. Numbers in brackets show fraction of illite in the clay fraction, when necessary are two values shown and separated by comma. 
grass under restricted availability (Mengel \& Steffens, 1985). The farmers may consider two main strategies to reduce the field level Kdeficiencies. One alternative is to reduce the number of cash crops in the rotation to increase the fodder production and thereby the animal density, and keep up with the principal aim of self-sufficiency with nutrients. According to Askegaard and Eriksen (2000), the field level K balances in organic farming systems are very dependent on animal density (AD). On the farms studied here, this strategy would have a notable impact only on Alm where the AD was $0.4 \mathrm{cow} \mathrm{ha}^{-1}$ (calculated from Table 2). Elsewhere the $\mathrm{AD}$ is approximately 1, and the number of cash crops is very restricted. On a larger scale, minimising cash crops will eliminate the production of organic cereals and vegetables for human consumption, which is not desired. The other alternative is to continue the present crop rotation and livestock, but increase the amount of purchased fodder or other nutrient inputs to the farm. This will be in conflict with the aim of self-sufficiency, but the soil fertility will be maintained or increased and this is also a principal goal of organic farming systems (IFOAM, 2002).

In addition to these considerations, care should be taken to minimise all losses of nutrients. All areas for outdoor storage and composting of animal manure, as well as recreation areas for cattle in winter, should be designed to ensure that runoff is properly collected and redistributed on the farmland. Care should also be taken to decrease nutrient losses during the treatment of fodder, and from soil and herbage during winter. However, because $\mathrm{K}$ is easily lost, such amendments will not be enough to ensure a sufficient $\mathrm{K}$-availability on all soil types.

\section{Relations between $\mathrm{P}$ and $\mathrm{K}$}

As shown by Watson et al. (2002), P and K are closely linked in nutrient balances on organic farms, due to a close correlation between $\mathrm{P}$ - and K-inputs. However, whereas the P-input was reflected in the P-output in products, no such relationship was found for $\mathrm{K}$ in that study. This may well be because $\mathrm{K}$ is more susceptible to internal losses, as described by Nolte and Werner (1994). In a study of 12 farms in the process of conversion to organic farming (Løes \& Øgaard, 1997), the accumulated surplus of $\mathrm{P}$ on farm level was well correlated with the average changes in soil P-AL concentrations over 6 years, whereas for $\mathrm{K}-\mathrm{AL}$, there was no correlation to the accumulated surplus of potassium. This result also reflects the dynamic nature of $\mathrm{K}$, where internal losses and changes in soil occur more rapidly. On the converting farms, both K-AL and P-AL in topsoil was significantly reduced, on average from 141 to $117 \mathrm{mg} \mathrm{K}$ and from 129 to 124 mg $\mathrm{P} \mathrm{kg}^{-1}$ soil, respectively. A clear common characteristic for soil P-AL and K-AL concentrations was that the largest decreases were found for the fields where the initial nutrient concentrations were very high or high, whereas on fields with low concentrations, the concentrations increased over time (Løes \& Øgaard, 1997). The same pattern was found for P-AL after long-term organic farming (Løes \& Øgaard, 2001).

In the present study of long-term organic farms, $\mathrm{P}$ and $\mathrm{K}$ soil concentrations behaved quite differently. Whereas the P-AL concentrations decreased, the soil K-AL concentrations did not. Even if both nutrients were found to decrease on converting farms, it is reasonable that the soil P-AL concentrations decreased for a longer period than K-AL. This is because of the very different nature of these plant nutrients in soil, and the larger risk of losing $\mathrm{K}$ from the farm nutrient cycle. For $\mathrm{P}$, indications of increased subsoil concentrations, as well as a higher degree of solubility of the organic soil $\mathrm{P}$ by long-term organic farming were found (Løes \& Øgaard, 2001). Such results demonstrate that in addition to nutrient balances, more detailed studies are required to describe farm nutrient dynamics.

\section{Organic farming standards}

The IFOAM Basic Standards are guidelines for development of national standards for organic farming (IFOAM, 2002). Until recently, the term 'restricted' was applied to mineral potassium fertilisers and natural phosphates in the standards' appendix listing fertilisers and soil conditioners allowed for use in organic farming, whereas no such term was applied, for example, to lime amendments. The term 'restricted' was removed from all fertilisers by a revision of the Basic Standards in 2002, but 
it is still in use for mineral K-fertilisers and natural phosphates in national standards. Then the use of these fertilisers may be allowed if the farmers apply for it, based on documentation of suboptimal concentrations in soil. In Scandinavian countries, especially Sweden and Denmark, such applications are very rare. In Sweden, no use of mineral K-fertiliser or natural phosphate has been allowed for several years because no farmers have applied (A. Gustafsson, personal communication). In Denmark, the number of farmers applying for K-fertilisers during the last 6 years (1997-2002) varied between 0 and 2 per year (M. Andersen, personal communication). Nobody applied for the use of natural phosphates. In Norway, more farmers have applied. Altogether, 152 farmers were allowed to use mineral K-fertiliser, natural phosphate and/or micronutrients for periods of 1 or more years in 2000. In 2001, 17 additional farmers applied (P. Almaas, personal communication). Hence, approximately $8 \%$ of the Norwegian organic farmers have applied for approval to use mineral K-fertilisers, natural phosphates and/or micronutrients. A reason for fewer farmers applying in Sweden and Denmark may be that the use of vinasse, an organic residue from yeast production containing $\mathrm{K}$, is more common in these countries, and that more conventional animal manure is available, especially in Denmark.

The low numbers of farmers applying for use of mineral K-fertiliser may indicate that there are no problems with K-deficiency in organic farming in Scandinavia. However, it is also possible that organic farmers value the aim of self-sufficiency so highly that the important aim of maintaining or increasing the soil fertility (IFOAM, 2002) is sacrificed. We think that the low soil K-concentrations found with selfsufficient long-term organic dairy farming on $25-50 \%$ of the fields in the present study show that the restrictions on mineral K-fertilisers are imposed more rigorously than might in fact be intended by the basic standards.

\section{The sustainability of organic, self- sufficient dairy farming}

It must be emphasised that the present results were found after long-term organic dairy farming in systems where a principal aim was to produce food (milk and meat) for sale by a minimum input of nutrients. As described by Watson et al. (2002), the average $\mathrm{P}$ and $\mathrm{K}$ farm level budgets varies from a large surplus in organic horticultural systems based on purchased manure, to almost zero in organic dairy systems. Within organic dairy systems, the budgets on farm level varied from a deficit of -7 to a surplus of $36 \mathrm{~kg} \mathrm{P} \mathrm{ha-1} \mathrm{y}^{-1}$, and from -27 to $58 \mathrm{~kg} \mathrm{~K} \mathrm{ha}^{-1} \mathrm{y}^{-1}$. In the present study, the budgets varied from -3 to $12 \mathrm{~kg} \mathrm{P}$ and

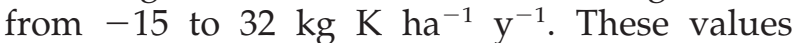
are within the interval of variation found by Watson et al. (2002), where data from more than 50 dairy farms were compiled. With respect to $\mathrm{K}$, we have claimed that the average field level balance was negative on the farms studied here, and we argue that it will usually be in selfsufficient organic dairy systems. Careful management of fodder and manure may reduce deficits, but zero losses are impossible to achieve with a nutrient as soluble as potassium. With respect to $\mathrm{P}$, a certain surplus of $\mathrm{P}$-fertiliser is required on field level to maintain the P-AL level constant, because of the adsorption of this nutrient in the soil in forms not extractable by the AL-solution. The P-balances for the five farms studied here obviously were not high enough to maintain the soil P-AL concentrations. In the paper presenting P-results it was concluded that inputs of $\mathrm{P}$ would be required within the next $20-40$ years to avoid that soil P-concentrations sink below a critical level of $30 \mathrm{mg}$ P-AL kg-1 soil (Løes \& Øgaard, 2001). Hence, for self-sufficient organic dairy farms with medium to low soil P-concentrations, appropriate P-inputs should be found within a few years. For farms with high or very high concentrations, it will be more sustainable to gradually reduce soil P-concentrations by field level P-deficits than to maintain high concentrations.

As the soil fertility is heavily dependent on soil nutrient availability, long-term field level deficits cannot be assessed as sustainable when the deficits are larger than the soil's ability to mineralise or otherwise release nutrients. Some soils possess a relatively large ability to supply plants with $\mathrm{K}$, especially soils rich in mica (Munn et al., 1976) and clay soils (Øgaard et al., 2002). Also, much agricultural soil in industrialised countries has been enriched with $\mathrm{P}$ for decades, resulting in $\mathrm{P}$ concentrations that cause severe negative environmental impacts (e.g. Sibbesen \& Sharpley, 1997). In such cases, field 
level nutrient deficits may be sustainable. In less fertile soils, required plant nutrients should be supplied as appropriate inputs to the farming system. In organic farming, both social, environmental and product quality aspects must be considered to decide which inputs are appropriate.

\section{Conclusion}

Based on farm level nutrient balances, the present study has shown that organic farming systems tend to be both $\mathrm{P}$ - and K-deficient on the field level even with dairy production, when the farmers aim at a self-sufficient farming system. Hence in the future, appropriate inputs should be used more frequently in organic farming systems, provided soil analysis or plant deficiency symptoms demonstrate that nutrients should be applied to the soil. Reduced yields may well occur without visible symptoms of nutrient deficiency, and it is important to define criteria for evaluation of the soil nutrient status within organic farming systems. The need for organic farmers to monitor soil P- and $\mathrm{K}$-concentrations regularly is probably larger than for conventional farmers. With respect to $\mathrm{K}$, acid-soluble $\mathrm{K}$ should be measured in addition to easily extractable $\mathrm{K}$, since this characteristic is related to the soil's ability to release $\mathrm{K}$ from reserve $\mathrm{K}$ (Øgaard et al., 2002). To assess the K-availability and fixation capacity of the soil, knowledge of soil mineral texture is very useful. The topsoil minimum level of K-AL has proven useful for Norwegian soils (Øgaard et al., 2002), and a corresponding characteristic has also been suggested by other authors (Sharpley \& Buol, 1987). The minimum level provides a basis for interpreting recent values of available soil $\mathrm{K}$ and planning manure distribution within the framework of the crop rotation.

In future, recycling of nutrients back to agriculture, as well as the utilisation of natural resources, such as mineral potassium salts and phosphate rock, will be required to ensure and increase soil fertility in organic farming systems. There is an urgent need for research to consider and develop sustainable nutrient inputs that can be used in accordance with organic farming standards.

\section{Correspondence}

Any correspondence should be directed to A.K. Løes, Norwegian Centre for Ecological Agriculture (NORSØK), N-6630 Tingvoll, Norway (anne.k.loes@norsok.no).

\section{References}

Asdal, Å. and Bakken, A.K. (1999) Nutrient balances and yields during conversion to organic farming in two crop rotation systems. In J.E. Olesen, R. Eltun, M.J. Gooding, E.S. Jensen and U. Köpke (eds). Designing and Testing Crop Rotations for Organic Farming (pp. 125-132). FØJO Report no 5.

Askegaard, M. and Eriksen, J. (2000) Potassium retention and leaching in an organic crop rotation on loamy sand as affected by contrasting potassium budgets. Soil Use and Management 16, 200-205.

Björklund, J. and Salomon, E. (1995) Växtnäringsflöden i ekologiskt lantbruk - resultat från forsöksgården Tingvall. Fakta Mark/växter 6, Swedish University of Agricultural Sciences, Uppsala.

Brown, G. (1961) X-ray Identification and Crystal Structures of Clay Minerals. London: Mineralogical Society.

Ebbesvik, M. (1997) Nøkkeltall fra 13 gårder med økologisk drift. Resultater og kommentarer (p. 192). Tingvoll, Norway: Norwegian Centre for Ecological Agriculture.

Egnér, H., Riehm, H. and Domingo, W.R. (1960) Untersuchungen über die chemische Boden-Analyse als Grundlage für die Beurteilung des Nährstoffzustandes der Boden. Kungliga Lantbrukshögskolans Annaler 26, 199-215.

Elonen, P. (1971) Particle-size analysis of soil. Acta Agricultura Fennica 122, 1-122.

Eltun, R., Fugleberg, O. and Nordheim, O. (1996) The Apelsvoll cropping system experiment VII. Runoff losses of soil particles, phosphorus, potassium, magnesium, calcium and sulphur. Norwegian Journal of Agricultural Science 10, 371-384.

Eltun, R., Korsæth, A. and Nordheim, O. (2002) A comparison of environmental, soil fertility, yield and economical effects in six cropping systems based on an 8-year experiment in Norway. Agriculture, Ecosystems and Environment 90, 155-168.

Fagerberg, B., Salomon, E. and Jonsson, S. (1996) Comparisons between conventional and ecological farming systems at Öjebyn. Nutrient flows and balances. Swedish Journal of Agricultural Research 26, 169-180.

Gjems, O. (1967) Studies on clay minerals and claymineral formation in soil profiles in Scandinavia. Meddelelser fra Det Norske Skogforsøksvesen 21, 303415.

IFOAM (International Federation of Organic Agricultural Movements) (2002) http://www.ifoam.org

Kerner, K.N. (1993) Næringshusholdning i økologisk landbruk. Del 1: Handelsbalanser for nitrogen, fosfor og kalium på gårdene i 30 bruks-prosjektet. Faginfo 20, Statens fagtjeneste for landbruket, Ås, $1-32$. 
Kristensen, I.S. and Halberg, N. (1995) Markens nettoudbytte, næringsstofforsyning og afgrødetilstand på økologiske og konventionelle kvægbrug. In E.S. Kristensen (ed.) Økologisk Landbrug med Udgangspunkt i Kvaegbedriften. Landbrugsministeriet, Statens husdyrbrugsforsøg intern rapport 42, 42-44.

Leinweber, P., Reuter, G. and Vàgò, I. (1991) KaliumBilanzen und Mineralveränderungen in einigen Dauerdungsversuchen. Kali-Briefe 20, 597-604.

Lockeretz, W., Shearer, G., Sweeney, S., Kuepper, G., Wanner, D. and Kohl, D.H. (1980) Maize yields and soil nutrient levels with and without pesticides and standard commercial fertilizers. Agronomy Journal 72, 65-72.

Løes, A.K. and A.F. Øgaard (1997) Changes in the nutrient content of agricultural soil on conversion to organic farming, in relation to farm level nutrient balances and soil contents of clay and organic matter. Acta Agricultura Scandinavica Section B, Soil and Plant Science 47, 201-214.

Løes, A.K. and Øgaard, A.F. (2001) Long-term changes in extractable soil phosphorus (P) in organic dairy farming systems. Plant and Soil 237, 321-332.

Løes, A.K., Ebbesvik, M., Strøm, T. and Vittersø, H. (1999) Solli - en biologisk-dynamisk melkeproduksjonsgård i Vestfold (p. 48). Tingvoll, Norway: Norwegian Centre for Ecological Agriculture.

Martin, W.E. and Matocha, J.E. (1973) Plant analysis as an aid in the fertilization of forage crops. In L.M. Walsh and J.D.Beaton (eds) Soil Testing and Plant Analysis, (rev edn) (pp. 393-426). Madison, WI: Soil Science Society of America.

Mayer, J. (1997) Ist die Kaliumversorgung ausreichend und gesichert? Ökologie und Landbau 25, 30-33.

Mengel, K. and Steffens, D. (1985) Potassium uptake of rye-grass (Lolium perenne) and red clover (Trifolium pratense) as related to root parameters. Biology and Fertility of Soils 1, 53-58.

Munn, D.A., Wilding, L.P. and McLean, E.O. (1976) Potassium release from sand, silt and clay separates. Soil Science Society of America Journal 40, 364366.

Møberg, J.P. and Nielsen, J.D. (1983) Mineralogical changes in soils used for potassium-depletion experiments for some years in pots and in the field. Acta Agricultura Scandinavica 33, 21-27.

Niederbudde, E.A., Kaubrügger, H. and Flessa, H. (1989) Veränderungen von Tonböden bei alternativökologischen und konventionellen Anbauverfahren. Journal of Agronomy and Crop Science 162, 217-224.

Nielsen, J.D. and Møberg, J.P. (1984) The influence of K-depletion on mineralogical changes in pedons from two field experiments and in soils from four pot experiments. Acta Agricultura Scandinavica 34, 391-399.

Nolte, C. and Werner, W. (1994) Investigations on the nutrient cycle and its components of a biodynamically-managed farm. Biological Agriculture and Horticulture 10, 235-254.

Oehl, F., Oberson, A., Tagmann, H.U., Besson, J.M., Dubois, D., Mäder, P., Roth, H.-R. and Frossard, E. (2002) Phosphorus budget and phosphorus availability in soils under organic and conventional farming. Nutrient Cycling in Agroecosystems 62, 2535.

Poutala, R.T., Kuoppamaki, O., Korva, J. and Varis, E. (1994) The performance of ecological, integrated and conventional nutrient management systems in cereal cropping in Finland. Field Crops Research 37, 3-10.

Pratt, P.F. (1965) Potassium. In C.A. Black (ed.) Methods of Soil Analysis Part 2: Chemical and Microbiological Properties (pp. 1023-1031). Madison, WI: American Society of Agronomy.

Reganold, J.P., Elliott, L.F. and Unger, Y.L. (1987) Long-term effects of organic and conventional farming on soil erosion. Nature 330, 370-372.

Riley, H. (1996) Estimation of physical properties of cultivated soils in southeast Norway from readily available soil information. Norwegian Journal of Agricultural Science Suppl. 25, 1-51.

SAS Institute (1987) $S A S / S T A T^{\mathrm{TM}}$ Guide for Personal Computers, 6th edn. Cary, NC: SAS Institute Inc.

Schachtschabel, P., Blume, H.-P., Brümmer, G. Hartge, K.H. and Schwertmann, U. (1998) Lehrbuch der Bodenkunde (p. 494). Stuttgart: F Enke Verlag.

Schjønning, P., Elmholt, S., Munkholm, L.J. and Debosz, K. (2002) Soil quality aspects of humid sandy loams as influenced by organic and conventional long-term management. Agriculture Ecosystems and Environment 88, 195-214.

Sharpley, A.N. and Buol, S.W. (1987) Relationship between minimum exchangeable potassium and soil taxonomy. Communications in Soil Science and Plant Analysis 18, 601-614.

Sibbesen, E. and Sharpley, A.N. (1997) Setting and justifying upper critical limits for phosphorus in soils. In H. Tunney, O.T. Carton, P. Brookes and A.E. Johnston (eds) Phosphorus Loss from Soil to Water (pp. 151-176). New York: CAB International.

Statens forurensningstilsyn (SFT, Norwegian Pollution Control Authority) (1991) Overvåking av langtransportert forurenset luft og nedbør. Årsrapport 1990. SFT rapport 466/91.

Statens forurensningstilsyn (SFT, Norwegian Pollution Control Authority) (1992) Overvåking av langtransportert forurenset luft og nedbør. Årsrapport 1991. SFT rapport 506/92.

Stockdale, E.A., Lampkin, N.H., Hovi, M., Keatinge, R., Lennartsson, E.K.M, Macdonald, D.W., Padel, S., Tattersall, F.H., Wolfe, M.S. and Watson, C.A. (2001) Agronomic and environmental implications of organic farming systems. Advances in Agronomy 70, 261-327.

Sveistrup, T.E. (1984) Retningslinjer for beskrivelse av jordprofil. Jord og Myr 2, 30-77.

Thomas, G.W. (1982) Exchangeable cations. In A.L. Page, R.H. Miller and D.R. Keeney (eds) Methods of Soil Analysis Part 2. Chemical and Microbiological Properties (pp. 159-165). Madison, WI: American Society of Agronomy.

Tributh, H., Boguslawski, E.v., Lieres, A.V., Steffens D. and Mengel K. (1987) Effect of potassium removal by crops on transformation of illitic clay minerals. Soil Science 143, 404-409.

USDA (1996) Keys to Soil Taxonomy (7th edn.) Wash- 
ington: US Department of Agriculture and Soil Conservation Service.

Watson, C.A., Bengtsson, H., Ebbesvik, M., Løes, A. K., Myrbeck, A., Salomon, E., Schroder, J. and Stockdale, E.A. (2002) A rewiew of farm-scale nutrient budgets for organic farms as a tool for management of soil fertility. Soil Use and Management 18 supplement, Soil Fertility in Organically Managed Soils 264-273.

Øgaard, A.F., Krogstad, T. and Lunnan, T. (2002) Ability of some Norwegian soils to supply grass with potassium $(\mathrm{K})$ - soil analyses as predictors of K supply from soil. Soil Use and Management 19, $1-9$.

Aasbø, B., Steinshamn, H., Krogstad, T. and Thuen,
E. (1999) Changes in phosphorus and potassium content of topsoil on conversion to organic dairy production. Nordisk Jordbrugsforskning 81, 152.

\section{Personal communications}

Almaas, P. (2002) Debio, (Norwegian certification body for organic farming), telephone interview, 4 October.

Andersen, M. (2002) Danish Plant Directorate (Danish certification body for organic farming), formal letter, 23 October.

Gustafsson, A. (2002) KRAV (Swedish certification body for organic farming), e-mail, 19 September. 